\title{
Continuous indomethacin and ranitidine with interleukin-2 in advanced renal carcinoma and melanoma: A preliminary report
}

Wilson C Mertens, MD, FRCPC, VIVIEN HC BRAMWELL, PHD, MBBS, FRCP, PEEYUSH K LALA, MBBS, PHD, Diponkar BanerJee, MB, ChB, FRCP, PhD, Femida GWadry-Sridhar, BSc Pharm, Walter Romano, MD

\begin{abstract}
WC Mertens, VhC Bramwell, PK Lala, D Banerjee, F Gwadry-Sridhar, W Romano. Continuous indomethacin and ranitidine with interleukin- 2 in advanced renal carcinoma and melanoma. Can $J$ Infect Dis 1992;3(Suppl B):133B-137B. Experimental work has shown that during the development of tumours, host macrophages can deactivate natural killer cells and suppress lymphokine-activated killer cell development, apparently through prostaglandin $\mathrm{E}_{2}$ production. Continuous indomethacin combined with interleukin (IL)-2 may totally eradicate experimental lung metastases. The preliminary results of a phase II trial of this combination are reported. Indomethacin 50 to $75 \mathrm{mg}$ tid and ranitidine $150 \mathrm{mg}$ bid are started at least one week before IL-2 and continued until disease progression. IL-2 is given by continuous infusion for three courses, each consisting of five days of treatment and six days of rest. IL-2 starting dose is $3.0 \times 10^{6}$ Cetus $\mathrm{U} / \mathrm{m}^{2}$ for the first course with escalation to $4.5 \times 10^{6}$ and $6.0 \times 10^{6} \mathrm{U} / \mathrm{m}^{2}$ if toxicity allows. Pressor agents are not used. Thirty-two renal carcinoma patients were registered with seven withdrawing early. Two complete and three partial responses were seen for a response rate of $(20 \%)$ for eligible and treated patients, or $(16 \%)$ for all entered patients. Minor responses were seen in three patients. Twenty-five melanoma patients have been registered thus far and 18 have been eligible to proceed with IL- 2 therapy. One complete and two partial responses have been seen. Two of these responses (one complete and one partial) were achieved on indomethacin and ranitidine alone, before starting IL- 2 .
\end{abstract}

Key Words: Indomethacin, Interleukin-2, Melanoma, Ranitidine, Renal carcinoma

\section{Administration continue d'indométhacine et de ranitidine associées à l'interleukine-2 dans le traitement du carcinome rénal et du mélanome avancés: Un rapport préliminaire}

RÉSUMÉ: Les experiences antérieures ont démontré que, pendant l'évolution des tumeurs, des macrophages-hôtes peuvent désactiver les cellules tueuses naturelles et supprimer le développement des cellules tueuses activées par les lymphokines, apparemment par la sécrétion de prostaglandine $\mathrm{E}_{2}$. L'administration continue d'indométhacine associée à l'interleukine-2 (IL-2) pourrait éliminer totalement les métastases du poumon induites expérimentalement. On rapporte les résultats préliminaires d'un essai de phase II portant sur cette combinaison. On débute l'indométhacine (50 à $75 \mathrm{mg}$ tid) et la ranitidine (150 mg) au moins une semaine avant l'IL-2 et on poursuit le traitement jusqu'à ce que la maladie progresse. L'IL-2 est administrée en enfusion continue en trois cures, comptant chacune cinq jours de traitement et six jours de repos. La dose de départ de l'IL-2 est de $3.0 \times 10^{6}$ Cetus U/m² pour la première cure, puis majorée à $4,5 \times 10^{6} \mathrm{U} / \mathrm{m}^{2}$ 
et à $6,0 \times 10^{6} \mathrm{U} / \mathrm{m}^{2}$, si le degré de toxicité est tolérable. Les agents presseurs ne sont pas utilisés. Trente-deux patients porteurs d'un carcinome rénal ont étê inscrits et sept d'entre eux ont rapidement interrompu le traitement. On note deux réponses complètes et trois réponses partielles, soit un taux de réponse de $20 \%$ pour les patients admissibles et traitês, ou de $16 \%$ pour tous les patients ayant participié à l'étude. On relève des réponses mineures chez trois patients. Vingt-cinq patients porteurs de mélanomes ont été inscrits jusqu'ici et 18 d'entre eux sont admissibles au traitement par l'IL-2. Une réponse complète et deux réponses partielles ont été notées. Deux de ces réponses, une complète et une partielle, ont été obtenues grâce à l'indométhacine ou à la ranitidine seule, avant l'institution du traitement par l'IL-2.

$\mathrm{M}$ ALIGNANT MELANOMA AND RENAL CARCINOMA ARE malignancies which are increasing in incidence $(1,2)$. Advanced forms of these diseases are currently, incurable by conventional treatment (surgery, radiotherapy and cytotoxic chemotherapy). In recent years, therapy with biological response modifiers, particularly human recombinant interleukin (IL)-2 has attracted considerable interest. Rosenberg and colleagues (3), using bolus IL-2 with adoptively transferred ex vivo generated lymphokine activated killer (LAK) cells noted a response rate of $33 \%$ in renal carcinoma, and $23 \%$ in melanoma. Responses in these tumour types were also seen by the National Cancer Institute Extramural Clinical Trials IL-2/LAK Working Group, although the response rate for renal carcinoma was substantially lower (4-7). The toxicity and cost of adoptive immunotherapy with IL-2 limits the clinical application of these regimens, and doses and schedules of IL-2 administration which would improve the cost benefit ratio are of interest.

During the development of transplanted and spontaneous tumours in mice, host natural killer cells are rapidly inactivated by prostaglandins (PG) (primarily $\mathrm{PGE}_{2}$ ) secreted by host macrophages appearing in lymphoid organs as well as the tumour site (8). $\mathrm{PGE}_{2}$ mediated immunosuppression has also been reported in human cancer patients. $\mathrm{PGE}_{2}$ released by macrophages isolated from tumour-bearing hosts can also suppress the polyclonal activation of T cells, generation of cytotoxic T lymphocytes, as well as the generation of LAK cell activity in vitro $(8,9)$. These observations suggest that release of $\mathrm{PGE}_{2}$ in vivo in the tumour-bearing host may have pansuppressor effects against functional activation of numerous effector cell lineages. The responsible mechanisms so far identified are inhibition of IL-2 production by otherwise stimulated T cells, and downregulation of IL-2 receptor production.

Further experiments have been reported recently by Lala and Parhar (9) using experimental lung metastases in B6 mice injected with B16Fl0 melanoma cells. Chronic indomethacin therapy by drinking water or a single course of IL-2 administered intraperitoneally for five days reduced the number of metastatic nodules by two-thirds. A single course of IL-2 therapy with chronic indomethacin completely, or nearly completely eradicated pulmonary metastases, and multiple courses of IL-2 combined with chronic indomethacin resulted in long term survival. Subsequent experiments showed that intermittent indomethacin administration given only at the times of IL-2 administration, gave results inferior to continuous indomethacin therapy and were indistinguishable from treatment with IL-2 alone (9).

Based on these animal studies, a phase II study was designed using chronic indomethacin with intermittent continuous venous infusion IL-2 in patients with advanced renal carcinoma and melanoma, a preliminary report follows.

\section{PATIENTS AND METHODS}

Patient population: This trial, performed under the auspices of the Cancer Treatment Evaluation Program of the National Cancer Institute includes patients who have histologically confirmed metastatic or unresectable malignant melanoma or renal carcinoma that cannot be cured by conventional therapy. Patients are required to have bi-dimensionally measurable disease and demonstrated progression of disease eight weeks prior to entry. Patients are required to have a World Health Organization (WHO) performance status of 2 or less and a life expectancy of at least two months. No chemotherapy is permitted in the four weeks prior to entry (six weeks for nitrosoureas). Radiotherapy is permitted for palliative doses not exceeding $30 \mathrm{~Gy}$, provided treatment is not to the sole site of measurable disease. Patients are excluded if pretreatment levels of bilirubin exceeded $20 \mu \mathrm{mol} / \mathrm{L}$, creatinine $120 \mu \mathrm{mol} / \mathrm{L}$ and serum transaminases (aspartate aminotranferase and alanine aminotransferase) exceeding two times laboratory upper limit of normal. Patients are required to have a leukocyte count of $4.0 \times 10^{9} / \mathrm{L}$ or greater, or granulocytes of $2.5 \times 10^{9} / \mathrm{L}$ or greater, and forced expiratory volume of at least $2.0 \mathrm{~L}$ (or at least $75 \%$ of predicted). History of primary malignancy other than basal cell carcinoma or surgically-treated stage 1 squamous cell carcinoma of the cervix, maintenance glucocorticoid or nonsteroidal anti-inflammatory agent therapy, proven peptic ulcer disease or history of unexplained gastrointestinal bleeding, symptomatic cardiovascular disease or history of congestive heart failure or recent myocardial infarction are exclusion criteria. Patients with intracranial metastases are excluded (most patients had computed tomography [CT] scan performed immediately prior to starting therapy with IL-2). Women of childbearing age must have a negative pregnancy test. Patients must be 13 years of age and give informed signed consent. This 
protocol was approved by the Review Board for Health Sciences Research Involving Human Subjects of the University of Western Ontario.

Indomethacin and ranitidine administration: $\mathrm{Pa}-$ tients eligible for the trial (but before the cranial CT) commence indomethacin $50 \mathrm{mg}$ every $8 \mathrm{~h}$ and ranitidine $150 \mathrm{mg}$ orally every $12 \mathrm{~h}$. Patients who develop nausea or dyspepsia reduce the dose of indomethacin to $25 \mathrm{mg}$ every $8 \mathrm{~h}$, and slowly increase to the original starting dose if symptoms permit. Dimenhydrinate and/or antacids are used to relieve further symptoms. If patient tolerance permits the dose of indomethacin is escalated to a maximum of $75 \mathrm{mg}$ every $8 \mathrm{~h}$ after the first round of the IL-2. Indomethacin and ranitidine are taken for at least seven days prior to IL-2 therapy, and continued at the maximally tolerated doses throughout IL-2 infusions and rest periods, and for at least one month after IL-2 therapy is completed. At that time the initial assessment of response is made.

Interleukin-2 administration: Patients are admitted to the general oncology ward with continuous nursing supervision. Human recombinant IL-2 (Cetus Corp, California) is administered by continuous intravenous infusion on days 1 to 5 , days 12 to 16 and days 23 to 27 , toxicity permitting. The starting dose of IL-2 is $3 \times$ $10^{6}$ Cetus $\mathrm{U} / \mathrm{m}^{2}\left(18 \times 10^{6} \mathrm{IU} / \mathrm{m}^{2}\right)$ daily for the first course with escalation to $4.5 \times 10^{6}$ Cetus $\mathrm{U} / \mathrm{m}^{2}\left(27 \times 10^{6} \mathrm{IU} / \mathrm{m}^{2}\right)$ daily for the next course and $6 \times 10^{6}$ Cetus $\mathrm{U} / \mathrm{m}^{2}\left(36 \times 10^{6}\right.$ $\mathrm{IU} / \mathrm{m}^{2}$ ) daily for the final course, if grade 3 toxicity (according to the National Cancer Institute common toxicity scale) is not reached. The IL-2 infusion is reduced or occasionally interrupted for hypotension not responsive to crystalloid fluid therapy, cardiac arrhythmia, prolonged oliguria (less than $100 \mathrm{~mL}$ over $8 \mathrm{~h}$ and not responding to diuretics), confusion and pulmonary edema. If grade 3 toxicity occurs the IL- 2 infusion rate is reduced by $50 \%$, with escalation to the original infusion rate as toxicity resolves. Every attempt is made to complete the planned dose of IL-2 administration for that particular course, and hence some infusions are prolonged beyond the planned five days. Patients who develop grade 4 toxicity are withdrawn from the trial.

Supportive care: Careful attention is paid to the patient's hemodynamic, fluid, pulmonary and cardiac status, but IL-2 is not administered in an intensive care unit setting, and monitoring is noninvasive. Hypotension is managed by the judicious use of intravenous crystalloid solutions, or with IL-2 infusion rate reduction; pressor agents are not used. Oliguria is managed with crystalloid solutions administered in small intravenous boluses, furosenmide with or without metolazone, and IL-2 infusion rate reduction or interruption as noted above, if not responsive to the above measures. In addition, acetaminophen $650 \mathrm{mg}$ every $8 \mathrm{~h}$ for fever and myalgias, hydroxyzine hydrochloride 50 to $100 \mathrm{mg}$ orally for pruritus, dimenhydrinate, prochlorperazine, metoclopramide or nabdone for nausea and loperamide hydrochloride for diarrhea are used as required.

Response assessment and retreatment: Patients are evaluated for response four weeks following completion of IL-2 therapy. Objective response is judged by standard phase II criteria as either complete or partial (10). Both complete and partial responses are required to be at least four weeks in duration from initial documentation.

Patients who obtain at least stable disease (insufficient shrinkage to be quoted as partial response, or tumour growth less than 25\%) are maintained on indomethacin at maximally tolerated doses, and ranitidine, until evidence of disease progression, or intolerance or contraindication to continuation of medication develops. In addition, all patients with evidence of shrinkage of measurable lesions, and remaining evaluable disease, are offered retreatment of IL-2 using three rounds of continuous venous infusion therapy as described above. Retreated patients maintained continuously on indomethacin and ranitidine are evaluated one month after IL-2 retreatment to judge further response, and continued on oral medication until intolerance or disease progression.

Sample size: Using Gehan's design, a maximum of 25 patients will be accrued for each tumour type. This will ensure that the response rate is estimated at the standard error of no more than $10 \%$ if a response rate of $20 \%$ or better is achieved (11).

\section{RESULTS}

Tumour response: Thirty-two renal carcinoma patients have been registered in the trial. Seven patients withdrew early from treatment (indomethacin intolerance in three patients; early IL-2-associated confusion; withdrawal after consent but before any treatment; and drop in performance status). A total of 25 patients went on to receive at least one full five-day course of IL-2 infusion. Two complete, and three partial responses were seen for an objective response rate of $20 \%$ for eligible and adequately treated patients or $16 \%$ for all entered patients. A further three patients had minor responses.

Thus far, 25 melanoma patients have been registered. Seven patients were withdrawn early (central nervous system metastases, five patients; and withdrawal after consent but before therapy, two patients). Thus far, one complete and two partial responses have been seen. Two of the responding patients (one complete and one partial responder) achieved the objective response on the combination of indomethacin and ranitidine before starting IL-2.

Toxicity: Thus far, toxicity data are available for 40 patients undergoing 117 courses of continuous infusion IL-2. Two patients required transfer to an intensive care unit after therapy. One patient developed polymicrobial sepsis five days after completing an intravenous course of IL-2 and required intubation. Another patient developed grade 4 hyperbilirubinemia as well as coma and 
TABLE 1

Toxicity summary for melanoma and renal cell patients

\begin{tabular}{|c|c|c|c|}
\hline & $\begin{array}{c}\text { Current } \\
\text { study* }(\%)\end{array}$ & $\begin{array}{c}\text { Rosenberg } \\
\text { (3) }^{\dagger}\end{array}$ & $\begin{array}{l}\text { Margolin } \\
(12)^{\dagger}\end{array}$ \\
\hline $\begin{array}{l}\text { Hypotension } \\
\text { requiring pressors }\end{array}$ & $0(0)$ & $123(68)$ & $70(74)$ \\
\hline Oliguria & $23(59)$ & $51(28)$ & $36(38)$ \\
\hline \multicolumn{4}{|l|}{ Neurological } \\
\hline Grade 3 & $7(12)$ & $64(50)$ & $30(32)$ \\
\hline Grade 4 & $1(2)$ & $9(5)$ & $4(4)$ \\
\hline Pulmonary & - & $16(9)$ & $5(5)$ \\
\hline Intubation required & $1(2)$ & - & - \\
\hline Cardiac arrhythmias & none & $24(13)$ & $20(21)$ \\
\hline $\begin{array}{l}\text { Supraventricular } \\
\text { tachycardia }\end{array}$ & none & $1(1)$ & $10(11)$ \\
\hline $\begin{array}{l}\text { Ventricular } \\
\text { tachycardia }\end{array}$ & none & none & $5(5)$ \\
\hline Atrial fibrillation & none & $n / a$ & $1(1)$ \\
\hline Ventricular ectopy & $1(2)$ & $\mathrm{n} / \mathrm{a}$ & $1(1)$ \\
\hline \multicolumn{4}{|l|}{ Infection } \\
\hline Requiring antibiotics & $13(33)$ & $23(13)$ & $10(11)$ \\
\hline Septic shock & $1(2)$ & $\mathrm{n} / \mathrm{a}$ & $2(2)$ \\
\hline \multicolumn{4}{|l|}{ Cardiovascular } \\
\hline $\begin{array}{l}\text { Angina without } \\
\text { infarction }\end{array}$ & $1(2)$ & $n / a$ & $4(4)$ \\
\hline Myocardial infarction & none & $4(2)$ & $4(4)$ \\
\hline Perforated viscus & none & $\mathrm{n} / \mathrm{a}$ & $2(2)$ \\
\hline $\begin{array}{l}\text { Gastrointestinal } \\
\text { hemorrhage }\end{array}$ & none & $n / a$ & $2(2)$ \\
\hline Death on treatment & none & $4(2)$ & $1(1)$ \\
\hline
\end{tabular}

oliguria which spontaneously resolved on arrival in the intensive care unit; invasive monitoring and intubation were not required. One patient developed symptoms of classical angina pectoris $3 \mathrm{~h}$ after completing therapy with IL-2 but electrocardiograms and serial serum measurements of creatine kinase and lactate dehydrogenase isoenzymes failed to document evidence of myocardial infarction.

One-third of patients treated thus far have required antibiotics at some point during the course of therapy. The vast majority of these infections were clinically infected intravenous sites, or superficial thrombopthlebitis at the site of intravenous appliances. Most of these presumed infections were culture negative, but were

ACKNOWLEDGEMENTS: Supported by a Grant from the National Cancer Institute of Canada

\section{REFERENCES}

1. Balch CM, Houghton A, Peters L. Cutaneous melanoma. In: DeVita VT Jr, Hellman S, Rosenberg SA, eds. Cancer: Principles and Practice of Oncology, 3rd edn. Philadelphia: JB Lippincott and Company, 1989:1499-542.

2. Lineham WM, Shipley WU, Longo D. Cancer of kidney and ureter. In: DeVita VT Jr, Hellman S, Rosenberg SA, eds. Cancer: Principles and Practice of Oncology, 3rd edn. treated with antibiotics based on clinical findings.

Compared with other studies $(3,12)$ this study has a relatively high rate of transient olguria. This is likely due to the fact that pressor agents such as phenylephrine or dopamine were not used. Table 1 summarizes specific toxicities and compares them to two previously published studies using IL-2 with LAK cell reinfusion $(3,12)$.

\section{DISCUSSION}

Accrual to this study is in its third year and nearing completion. The objective response rates seen with this regimen in patients with renal carcinoma and melanoma are comparable to response rates quoted in other studies of IL-2-based therapies. In renal carcinoma, it compares very favorably to results recently reported by the National Cancer Institute Extramural Clinical Trials IL-2/LAK Working Group using adoptively transferred LAK cells with either bolus IL-2 (4) or hybrid bolus in continuous venous IL-2 therapy (5).

Toxicity in the present study has thus far been substantial, but transient and manageable. Patients are managed successfully on a general oncology ward, without need for routine admission to intensive care units for monitoring and pressor agent support. The toxicity profile compares favorably with other IL-2based studies, without compromising response rates in renal carcinoma and melanoma. Response rates are still modest, however, and further research will be required before randomized studies are undertaken.

Most clinical trials of high dose IL-2 employ indomethacin and ranitidine in doses comparable with those employed in this study. The interesting observation of two objective responses in patients with advanced malignant melanoma with the combination of indomethacin and ranitidine before commencing IL-2 therapy suggests that indomethacin and ranitidine may have a modest response rate in advanced malignant melanoma, and some of the responses reported to IL-2based therapies in malignant melanoma might be attributable to indomethacin and ranitidine. This is the only study that routinely administers these two medications prior to IL-2 therapy and this result has stimulated a new phase II clinical trial that is currently being performed by the authors' group.

Philadelphia: JB Lippincott and Company, 1989:979-97.

3. Rosenberg SA, Lotze MT, Mull LM, et al. A progress report on the treatment of 157 patients with advanced cancer using lymphokine-activated killer cells and interleukin-2 or high-dose interleukin-2 alone. N Engl J Med 1987;316:889-97.

4. Fisher RI Coltman CA, Doroshow JH, et al. Metastatic renal cancer treated with interleukin-2 and lymphokine-activated killer cells. Ann Intern Med 1988;108:518-23.

5. Parkinson DR, Fisher RI, Rayner AA, et al. Therapy of renal cell carcinoma with interleukin-2 on lymphokineactivated killer cells: Phase II experience with a hybrid 
bolus and continuous infusion interleukin-2 regimen. J Clin Oncol 1990;8:1630-6.

6. Dutcher JP, Creekmore S, Weiss GR, et al. A phase II study of interleukin-2 and lymphokine-activated killer cells in patients with metastatic malignant melanoma. J Clin Oncol 1989;7:477-85.

7. Bar MH, Sznol M, Atkins MB, et al. Metastatic malignant melanoma treated with combined bolus and continuous infusion interleukin-2 and lymphokine-activated killer cells. J Clin Oncol 1990;8:1138-47.

8. Parhar RS, Lala PK. Amelioration of B16F10 melanoma lung metastasis in mice by a combination therapy with indomethacin and interleukin-2. J Exp Med 1987; 165:14-28.

9. Lala PK, Parhar RS. Cure of B165F10 melanoma lung metastasis in mice by chronic indomethacin therapy combined with repeated rounds of interleukin-2:

Characteristics of killer cells generated in situ. Cancer Res 1988;48:1072-9.

10. Hoogstraten B. Reporting treatment results in solid tumors. In: Buyse ME, Staquet MJ, Sylvester RJ, eds. Cancer Clinical Trials, Toronto: Oxford University Press, 1990:139-56.

11. Gehan EA. The determination of the number of patients required in preliminary and the follow-up trial of a new chemotherapeutic agent. J Chron Dis 1961;13:346-53.

12. Margolin KA, Rayner AA, Hawkins MV, et al. Interleukin-2 and lymphokine activated killer cell therapy of solid tumors: Analysis of toxicity and treatment guidelines. J Clin Oncol 1989;7:486-98. 


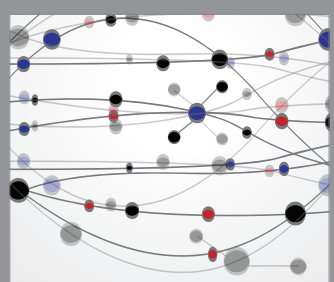

The Scientific World Journal
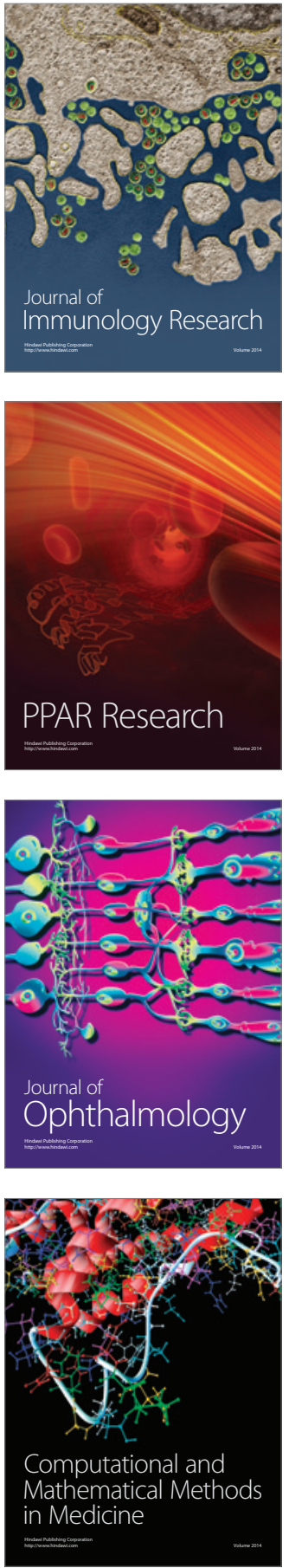

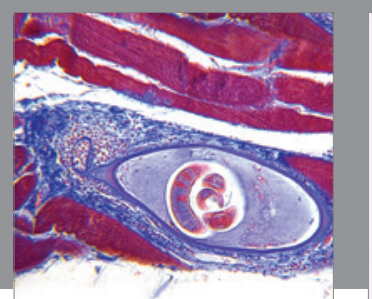

Gastroenterology Research and Practice

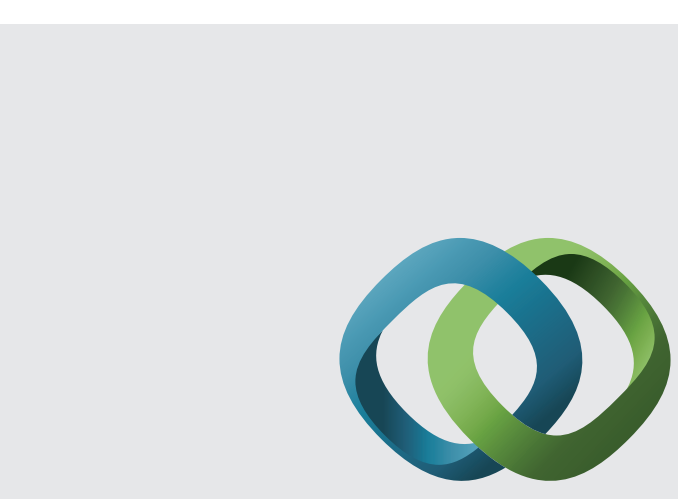

\section{Hindawi}

Submit your manuscripts at

http://www.hindawi.com
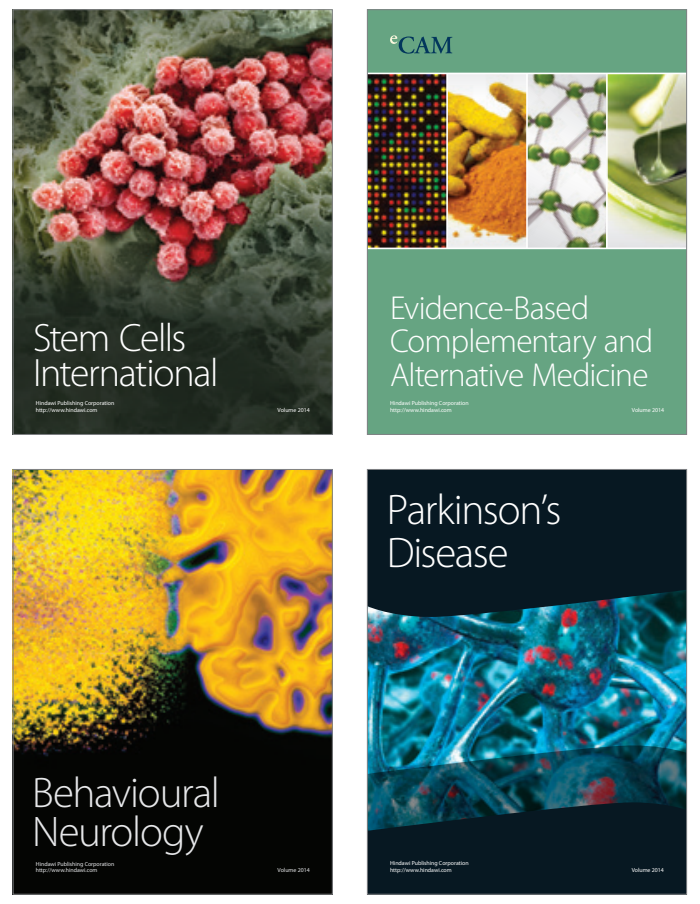
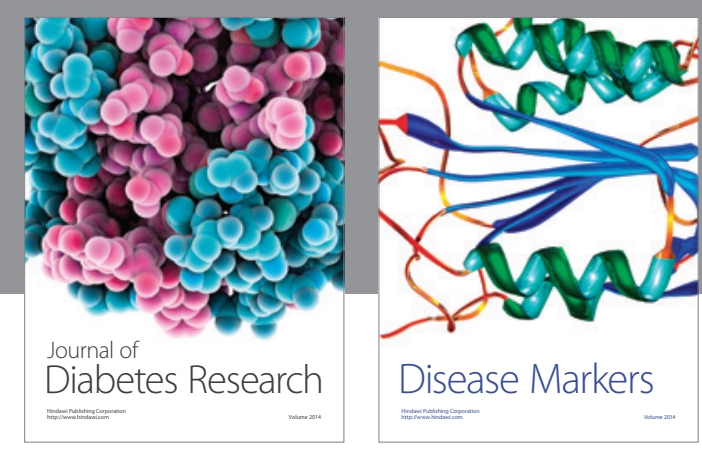

Disease Markers
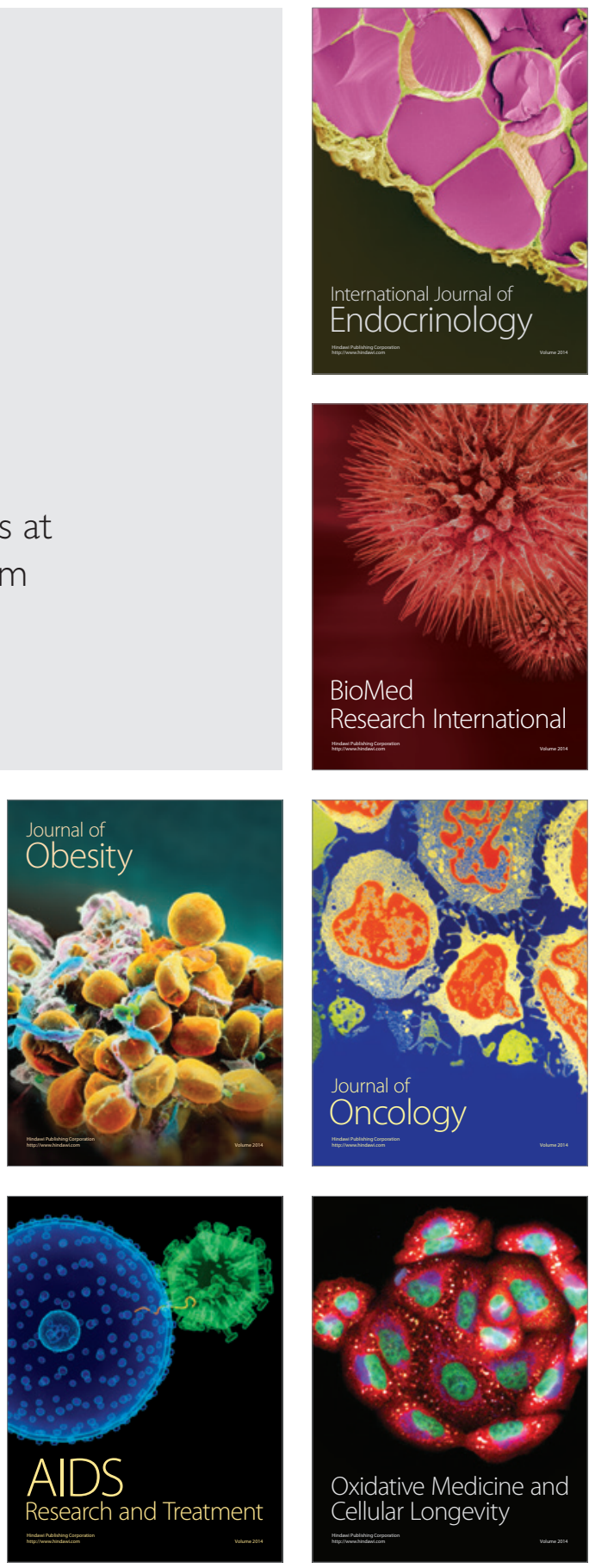